\title{
Penentuan bobot kayu apu Pistia stratiotes L. sebagai fitoremediator dalam pendederan ikan gurami Oshpronemus goramy Lac. ukuran $3 \mathrm{~cm}$
}

\section{Weight determination of water lettuce Pistia stratiotes $\mathbf{L}$. as phytoremediator in nursery of giant goramy Oshpronemus goramy Lac at size $3 \mathrm{~cm}$}

\author{
Kukuh Nirmala*, Sulistia Wardani, Yuni Puji Hastuti, Wildan Nurussalam \\ Departemen Budidaya Perairan, Fakultas Perikanan dan Ilmu Kelautan, Institut Pertanian Bogor \\ Kampus IPB Dramaga Bogor, Jawa Barat 16680 \\ *Surel: kukuhnirmala@yahoo.com
}

\begin{abstract}
The use of high stocking density in nursery causes a decrease of water quality. Technology that can be used to solvethe low water quality in nursery of giant goramy was phytoremediation using Pistia stratiotes L. Purpose of this research was to determine the best weight ratio between $P$. stratiotes L. and $33 \mathrm{~L}$ water in nursery giant goramy size $3 \mathrm{~cm}$. Giant goramy size $3 \mathrm{~cm}$ was maintained in an aquarium and was treated with different weight of P. stratiotes L. consisted of $45 \mathrm{~g}, 90 \mathrm{~g}, 135 \mathrm{~g}$, and controls P. stratiotes L. $0 \mathrm{~g}$. Cleaning and water change was done once a week. This research showed that the treatment of $P$. startiotes $\mathrm{L} .45 \mathrm{~g} / 33 \mathrm{~L}$ water gave the best result in survival rate, absolute length of the growth, specific growth rate, feed efficiency and economically profitable.
\end{abstract}

Keywords: phytoremediation, water lettuce, Osphronemus goramy L., nursery

\begin{abstract}
ABSTRAK
Penggunaan padat tebar tinggi pada pendederan ikan gurami mengakibatkan kualitas air menjadi buruk. Salah satu teknologi yang bisa digunakan untuk mengatasi kualitas air yang buruk pada pendederan ikan gurami adalah fitoremediasi menggunakan tanaman kayu apu Pistia stratiotes L. Tujuan penelitian ini adalah menentukan bobot kayu apu dengan volume air $33 \mathrm{~L}$ pada pendederan ikan gurami ukuran $3 \mathrm{~cm}$. Ikan gurami ukuran $3 \mathrm{~cm}$ dipelihara di dalam akuarium dan diberi perlakuan bobot tanaman kayu apu berbeda yaitu 45 g, 90 g, dan 135 g, serta kontrol (kayu apu 0 g). Penyiponan dan pergantian air dilakukan setiap satu minggu sekali. Hasil penelitian menunjukkan bahwa perlakuan kayu apu 45 g/33 L air menunjukkan hasil tingkat kelangsungan hidup, pertumbuhan panjang mutlak, laju pertumbuhan bobot harian, efisiensi pakan yang paling baik, serta lebih menguntungkan dibandingkan dengan perlakuan kontrol (kayu apu $0 \mathrm{~g}$ ).
\end{abstract}

Kata kunci: fitoremediasi, kayu apu, Oshpronemus goramy L., pendederan

\section{PENDAHULUAN}

Ikan gurami Oshpronemus goramy Lac. adalah ikan asli Indonesia khususnya yang berasal dari Propinsi Jawa Barat. Permasalahan yang didapat pada pendederan ikan gurami yaitu masalah kualitas air yang jelek dapat menurunkan produksi ikan gurami. Oleh karena itu diperlukan adanya perbaikan teknik pendederan ikan gurami agar jumlah produksi dan kualitasnya dapat terpenuhi. Pada umumnya para pembudidaya pendederan ikan gurami ukuran 2-3 cm menggunakan padat tebar 2-3
ekor/L dengan pergantian air yang dilakukan 3-4 kali dalam seminggu dan kelangsungan hidup yang diperoleh sebesar 60-80\%. Strategi atau upaya yang dapat diterapkan untuk meningkatkan produksi ikan gurami yaitu dengan menggunakan padat tebar tinggi. Namun penggunaan padat tebar tinggi mengakibatkan kualitas air menjadi buruk yang diakibatkan jumlah limbah semakin meningkat. Perbaikan kualitas air dalam hal ini bisa dilakukan dengan menggunakan tanaman air yang berfungsi menyerap kotoran dan juga 
gas-gas berbahaya dari sisa pakan maupun hasil metabolisme ikan. Teknologi yang memanfaatkan tanaman untuk mengurangi dampak limbah di wadah pemeliharaan yaitu dikenal dengan fitoremediasi. Fitoremediasi adalah pemanfaatan tumbuhan air untuk menghilangkan kontaminan berbahaya dari lingkungan seperti logam berat, pestisida, xenobiotik, senyawa organik, polutan aromatik beracun, dan drainase pertambangan yang asam (Hadiyanto et al., 2012). Keunggulan fitoremediasi dibandingkan dengan teknologi pengolahan limbah yang lain adalah prosesnya yang alami, adanya hubungan yang sinergi antara tanaman, mikroorganisme, dan lingkungan atau habitat hidup, serta tidak diperlukan teknologi tinggi. Kelebihan tersebut menyebabkan biaya operasi proses fitoremediasi relatif lebih rendah dibandingkan dengan metode lain (Purwaningsih, 2009).

Fitoremediasi merupakan penggunaan tumbuhan untuk menghilangkan, memindahkan, menstabilkan, dan menghancurkan bahan pencemar baik itu senyawa organik maupun anorganik. Beberapa tanaman air dapat digunakan sebagai fitoremediator berbagai limbah diperairan. Fitria et al. (2014) menggunakan tanaman genjer untuk mengurangi kadar logam berat $(\mathrm{Pb}$ dan $\mathrm{Cu})$ serta radionuklida dalam air.

Penelitian Marda et al. (2015) menggunakan fitoremediator tanaman Lemna perpusilla dan hasilnya memberikan pengaruh yang baik terhadap kualitas air, kelangsungan hidup dan pertumbuhan panjang harian ikan gurami bobot $17,57 \pm 0,92$ g. Kayu apu Pistia stratiotes salah satu tanaman air yang mengapung dipermukaan air atau yang dikenal dengan floating plant. Tanaman ini hidup dari menyerap udara dan unsur hara yang terkandung dalam air. Selain itu tanaman $P$. stratiotes bisa memfilter, mengabsorpsi partikel dan ion-ion logam yang terdapat dalam air limbah melalui akar (Wirawan, 2014). Lu et al. (2008) dalam penelitiannya mengatakan $P$. stratiotes mampu menurunkan kekeruhan hingga $60 \%$ dan berpotensi menghilangkan unsur $\mathrm{N}$ (nitrogen) dan P (fosfor) dari stromwater eutrofik dan meningkatkan kualitas air lainnya. Marda (2015) menjelaskan bahwa penggunaan tanaman Lemna perpusilla dapat menjaga kualitas air media pemeliharaan ikan gurame. Penelitian ini bertujuan untuk menentukan bobot kayu apu $P$. stratiotes dengan volume air $33 \mathrm{~L}$ pada pendederan ikan gurami ukuran $3 \mathrm{~cm}$ dengan harapan mampu menyerap limbah nitogen yang dihasilkan dari metabolisme ikan.

\section{BAHAN DAN METODE}

\section{Rancangan percobaan}

Penelitian ini menggunakan rancangan acak lengkap terdiri atas empat perlakuan dan masingmasing tiga ulangan. Perlakuan yang digunakan yaitu perbedaan bobot kayu apu pada volume air 33 L. Perlakuan terdiri atas :

Kontrol : kayu apu dengan bobot $0 \mathrm{~g}$

Perlakuan A : kayu apu dengan bobot $45 \mathrm{~g}$

Perlakuan B : kayu apu dengan bobot $90 \mathrm{~g}$

Perlakuan C : kayu apu dengan bobot $135 \mathrm{~g}$

\section{Persiapan wadah}

Persiapan dimulai dengan mencuci akuarium berukuran $49 \times 30 \times 32 \mathrm{~cm}$ sebanyak 12 buah dengan volume air $33 \mathrm{~L}$, dan satu tandon air bervolume $1.000 \mathrm{~L}$. Seluruh peralatan dicuci bersih dan disterilisasi menggunakan PK (kalium permanganat) lalu didiamkan selama satu hari. Kemudian seluruh akuarium dibilas hingga bersih. Seluruh akuarium diatur dan dipasang peralatan aerasi.

\section{Persiapan hewan uji}

Hewan uji dalam penelitian ini adalah ikan gurami yang dibeli dari pembudidaya ikan di daerah Cimanggu. Padat tebar dalam kolam percoabaan adalah 6 ekor/L untuk masingmasing perlakuan. Panjang total rata-rata awal sebesar 3,29 $\pm 0,076 \mathrm{~cm}$ dan bobot rata-rata awal $0,6 \pm 0,027 \mathrm{~g}$, selain itu juga disiapkan tanaman air kayu apu dengan panjang akar $\pm 15 \mathrm{~cm}$.

\section{Pemeliharaanikan,tanaman, dan pengambilan sampel}

Pemeliharaan ikan gurami dan tanaman kayu apu berlangsung selama 30 hari. Selama masa pemeliharaan dilakukan penyifonan dan pergantian air setiap satu minggu sekali setelah dilakukan pengukuran kualitas air. Pergantain air dilakukan sebanyak $80 \%$ dari volume awal. Pergantian tanaman kayu apu setiap satu minggu sekali masing-masing sebanyak jumlah perlakuan. Hal ini dilakukan agar efektivitas tanaman kayu apu dapat berjalan dengan baik. Selama masa pemeliharaan, ikan gurami diberi pakan berupa cacing sutra Tubifex sp. Pemberian pakan dilakukan secara at satiation (sekenyangnya). Pakan diberikan dengan cara ditebar ke setiap akuarium. Frekuensi pemberian pakan yaitu dua kali sehari pada pukul 08.00 WIB dan 16.00 WIB. Pengukuran panjang dan bobot dilakukan setiap satu minggu sekali untuk mengetahui 
pertumbuhan dari ikan gurami. Jumlah ikan gurami yang diambil sampel sebanyak 30 ekor/ akuarium.

\section{Pengelolaan kualitas air}

Air tawar yang digunakan berasal dari tandon penampungan. Pengelolaan kualitas air dilakukan dengan cara metode pergantian air sebanyak $80 \%$ dari volume awal dan dilakukan penyifonan pada dasar akuarium setiap satu minggu sekali. Pengukuran kualitas air seperti dissolved oxygen (DO), suhu, dan $\mathrm{pH}$ dilakukan setiap hari. Parameter total ammonia nitrogen (TAN), nitrit, nitrat, kekeruhan, dan fosfat dilakukan setiap satu minggu sekali.

\section{Parameter uji dan analisis data}

Parameter yang dievaluasi pada penelitian ini meliputi: parameter kualitas air yang terdiri atas suhu, $\mathrm{pH}, \mathrm{DO}$ (pengukuran menggunakan alat), TAN, nitrit, nitrat, fosfat, kekeruhan (pengukuran menggunakan spektrofotometer) (APHA, 1989), tingkat kelangsungan hidup (Effendie, 1997), laju pertumbuhan harian (Effendie, 1997), pertumbuhan panjang mutlak (Effendie, 1997), efisiensi pakan (Zonneveld et al., 1991), dan perhitungan ekonomi.

Analisis data pada penelitian ini menggunakan Microsoft Excel 2010 dan SPSS 16.0 yang disajikan dalam bentuk tabel dan grafik. Data dianalisis menggunakan analisis ragam ANOVA pada selang selang kepercayaan $95 \%$. Data tingkat kelangsungan hidup (SR), laju pertumbuhan harian (LPH), pertumbuhan panjang harian dan efisiensi pakan (EPP) yang berbeda nyata akan diuji lanjut menggunakan uji lanjut Tukey. Data konsentrasi sisa amonia, nitrit, nitrat, kekeruhan, fosfat, dan biaya keuntungan dianalisis secara deskriptif kuantitatif.

\section{HASIL DAN PEMBAHASAN}

\section{Hasil}

\section{Suhu, $p H$, dan DO}

Nilai kisaran suhu, $\mathrm{pH}$, dan $\mathrm{DO}$ yang diukur selama penelitian disajikan pada Tabel 1 . Nilai suhu perlakuan kayu apu 0 g, 45 g, 90 g, dan 135 g yang didapat berkisar $24,5-25,33{ }^{\circ} \mathrm{C}$, nilai $\mathrm{pH}$ 7,50-7,73; nilai DO sebesar 7,23-7,77 mg/L.

\section{Amonia}

Gambar 1 menunjukkan bahwa konsentrasi sisa amonia menggunakan fitoremediasi kayu apu $0 \mathrm{~g}$ cenderung meningkat setiap minggunya, sedangkan perlakuan fitoremediasi kayu apu 45 g cenderung menurun mulai dari minggu ketiga hingga minggu keempat. Perlakuan kayu apu 90 $\mathrm{g}$ dan $135 \mathrm{~g}$ menurun pada minggu ketiga dan meningkat pada minggu keempat. Konsentrasi sisa amonia tertinggi terdapat pada perlakuan kontrol (kayu apu $0 \mathrm{~g}$ ) minggu keempat yaitu sebesar $0,035 \mathrm{mg} / \mathrm{L}$ dan konsentrasi amonia yang menunjukkan hasil terendah pada perlakuan kayu apu $45 \mathrm{~g}$ minggu kesatu sebesar 0,006 mg/L (Gambar 1).

\section{Nitrit}

Gambar 2 menunjukkan bahwa konsentrasi sisa nitrit perlakuan fitoremediasi kayu apu $45 \mathrm{~g}$, $90 \mathrm{~g}$, dan 135 cenderung sama dan menurun setiap minggunya, dibandingkan dengan perlakuan fitoremediasi kayu apu $0 \mathrm{~g}$ yang cenderung meningkat. Konsentrasi nitrit tertinggi terdapat pada perlakuan kayu apu 0 g minggu kedua yaitu sebesar $1,335 \mathrm{mg} / \mathrm{L}$ dan konsentrasi nitrit terendah terdapat pada perlakuan kayu apu $45 \mathrm{~g}$ minggu keempat sebesar $0,975 \mathrm{mg} / \mathrm{L}$ (Gambar 2).

\section{Nitrat}

Konsentrasi sisa nitrat fitoremediasi kayu apu semua perlakuan menunjukkan hasil yang cenderung menurun setiap minggunya. Konsentrasi nitrat tertinggi terdapat pada perlakuan kayu 0 g minggu kedua yaitu sebesar $1,643 \mathrm{mg} / \mathrm{L}$ konsentrasi nitrat terendah terdapat pada perlakuan kayu apu $45 \mathrm{~g}$ minggu keempat sebesar 0,665 mg/L (Gambar 3).

\section{Fosfat}

Konsentrasi residu fosfat pada perlakuan fitoremediasi kayu apu 45 g, 90 g, dan $135 \mathrm{~g}$ menunjukkan hasil yang cenderung stabil setiap minggunya, sedangkan perlakuan kayu apu 0 g meningkat pada minggu ketiga dan menurun drastis minggu keempat. Konsentrasi sisa fosfat tertinggi terdapat pada perlakuan kayu apu 0 g minggu kedua yaitu sebesar $0,45 \mathrm{mg} / \mathrm{L}$ dan konsentrasi fosfat terendah terdapat pada perlakuan kayu apu $45 \mathrm{~g}$ minggu ketiga sebesar $0,032 \mathrm{mg} / \mathrm{L}$ (Gambar 4).

\section{Kekeruhan}

Konsentrasi sisa kekeruhan perlakuan kayu apu $45 \mathrm{~g}, 90 \mathrm{~g}$, dan $135 \mathrm{~g}$ cenderung meningkat pada minggu kesatu dan menurun hingga minggu keempat, sedangkan perlakuan kayu apu $0 \mathrm{~g}$ menunjukkan hasil yang cenderung meningkat pada minggu kedua dan menurun hingga minggu 
Tabel 1. Kisaran suhu, pH, dan DO harian selama 30 hari pemeliharaan ikan Oshpronemus goramy yang diberi kayu apu sebagai fitoremediator dengan rasio bobot berbeda

\begin{tabular}{lccccc}
\hline \multicolumn{1}{c}{ Parameter } & Tandon & Kontrol $(0 \mathrm{~g})$ & $\mathrm{A}(45 \mathrm{~g})$ & $\mathrm{B}(90 \mathrm{~g})$ & $\mathrm{C}(135 \mathrm{~g})$ \\
\hline Suhu $\left({ }^{\circ} \mathrm{C}\right)$ & 25,00 & $24,50-25,17$ & $25,00-25,17$ & $24,50-25,17$ & $25,17-25,33$ \\
$\mathrm{pH}$ & 8,64 & $7,57-8,26$ & $7,68-7,70$ & $7,50-7,72$ & $7,59-7,73$ \\
$\mathrm{DO}(\mathrm{mg} / \mathrm{L})$ & 8,20 & $6,17-6,83$ & $7,57-7,77$ & $7,23-7,60$ & $7,43-7,73$ \\
\hline
\end{tabular}

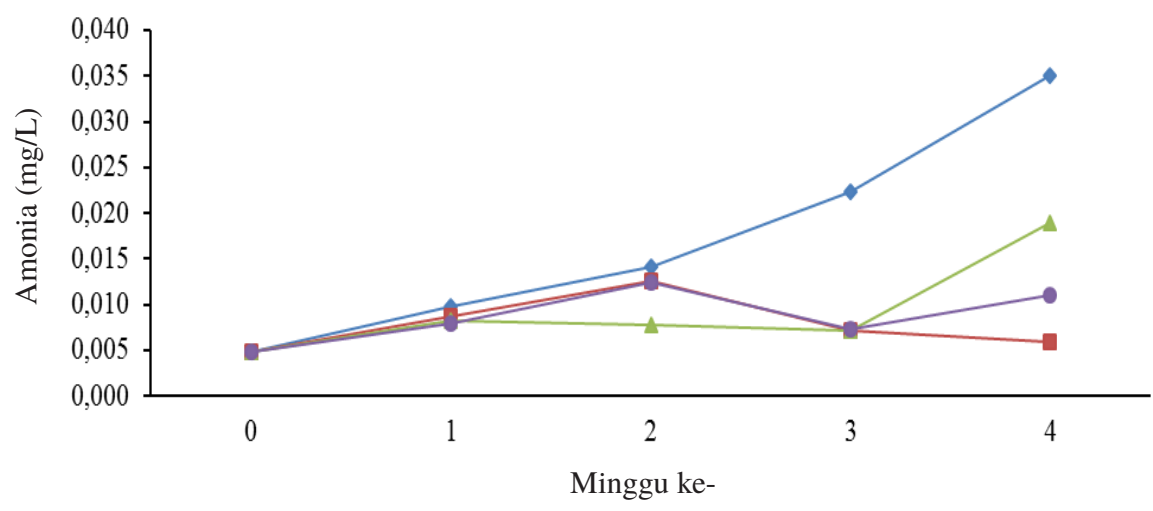

Gambar 1. Konsentrasi sisa amonia pada pendederan ikan Oshpronemus goramy di setiap minggu menggunakan

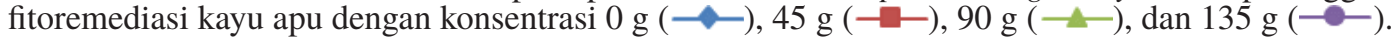

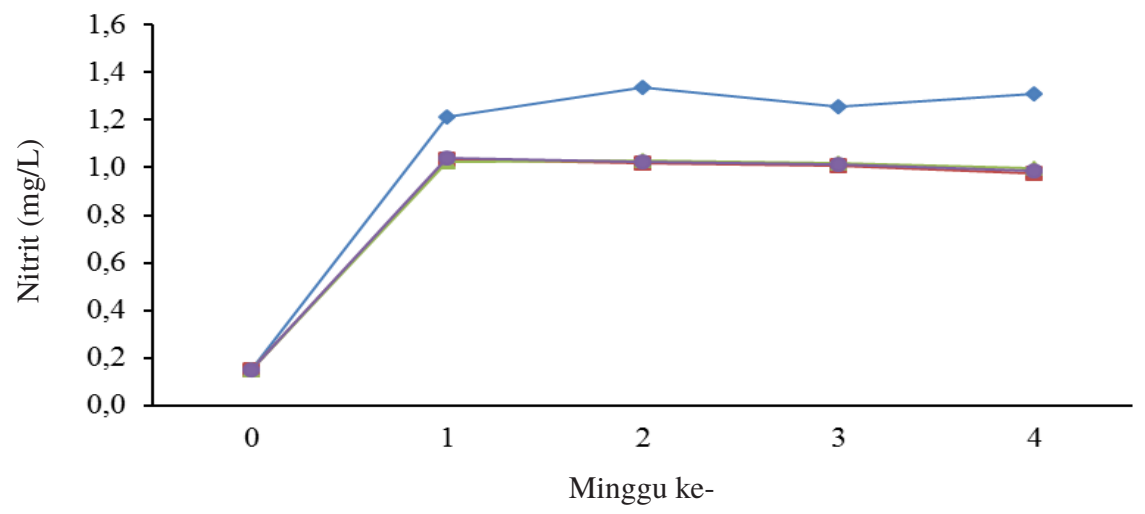

Gambar 2. Konsentrasi sisa nitrit pada pendederan ikan Oshpronemus goramy di setiap minggu menggunakan

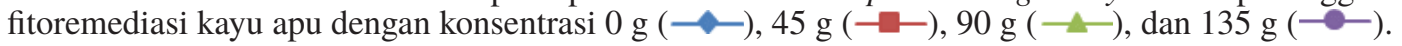

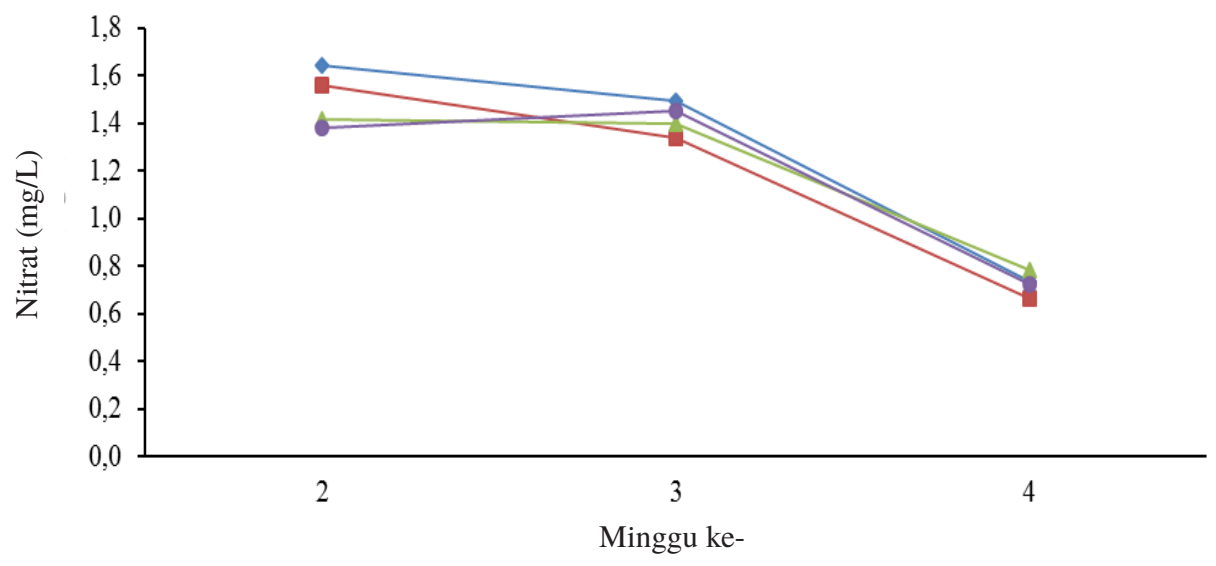

Gambar 3. Konsentrasi sisa nitrat pada pendederan ikan Oshpronemus goramy di setiap minggu menggunakan

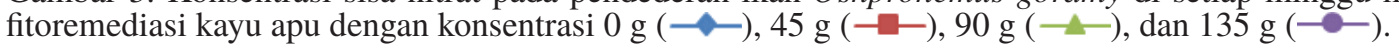


keempat. Konsentrasi kekeruhan tertinggi terdapat pada perlakuan kayu apu 0 g minggu ketiga yaitu sebesar 33,3 NTU dan konsentrasi kekeruhan terendah terdapat pada perlakuan kayu apu $90 \mathrm{~g}$ minggu keempat sebesar 3 NTU (Gambar 5).

\section{Tingkat kelangsungan hidup}

Nilai tertinggi tingkat kelangsungan hidup ikan gurami selama pemeliharaan 30 hari dicapai pada perlakuan kayu apu 45 g sebesar 96,33\% dan terendah pada perlakuan kontrol sebesar 24,5\% (Gambar 6). Berdasarkan uji statistik ragam (ANOVA) pada selang kepercayaan 95\%, nilai kontrol berbeda nyata dengan nilai tingkat kelangsungan hidup perlakuan kayu apu 45 g, 90 g dan $135 \mathrm{~g}(\mathrm{P}<0,05)$, sedangkan perlakuan kayu apu $45 \mathrm{~g}$ berbeda nyata dengan $90 \mathrm{~g}$ dan $135 \mathrm{~g}$.

\section{Laju pertumbuhan harian}

Nilai tertinggi laju pertumbuhan bobot harian didapat pada perlakuan kayu apu $45 \mathrm{~g}$ sebesar $3,46 \pm 0,19 \%$ dan nilai terendah terdapat pada kontrol sebesar 2,54 $\pm 0,02 \%$ (Gambar 7).
Berdasarkan uji statistik ragam (ANOVA) pada selang kepercayaan 95\% nilai kontrol berbeda nyata dengan nilai tingkat kelangsungan hidup perlakuan kayu apu $45 \mathrm{~g}$ dan $135 \mathrm{~g}(\mathrm{P}<0,05)$, dan nilai kontrol tidak berbeda nyata dengan perlakuan kayu apu $90 \mathrm{~g}(\mathrm{P}>0,05)$.

\section{Petumbuhan panjang mutlak}

Nilai tertinggi pengukuran panjang mutlak dicapai pada perlakuan kayu apu $45 \mathrm{~g}$ sebesar $0,93 \pm 0,036 \mathrm{~cm}$ dan terendah pada perlakuan

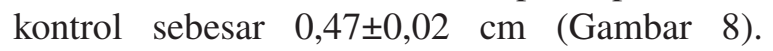
Berdasarkan uji statistik ragam (ANOVA) pada selang kepercayaan $95 \%$, nilai kontrol berbeda nyata dengan perlakuan kayu apu $45 \mathrm{~g}, 90 \mathrm{~g}$ dan $135 \mathrm{~g}(\mathrm{P}<0,05)$. Perlakuan kayu apu $45 \mathrm{~g}$ berbeda nyata dengan perlakuan kayu apu $90 \mathrm{~g}$ dan 135 $\mathrm{g}$, sedangkan perlakuan kayu apu $90 \mathrm{~g}$ dan $135 \mathrm{~g}$ tidak berbeda nyata.

\section{Efisiensi pakan}

Nilai tertinggi efisiensi pakan dicapai pada perlakuan kayu apu $45 \mathrm{~g}$ sebesar $22,61 \pm 1,71 \%$ dan terendah pada kontrol sebesar 17,62 $\pm 0,29 \%$

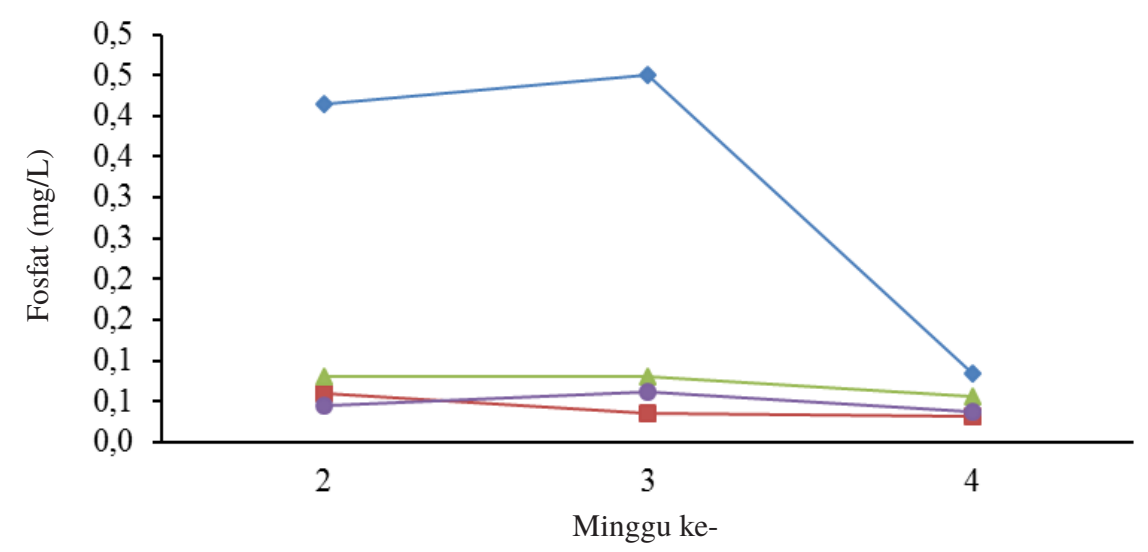

Gambar 4. Konsentrasi sisa fosfat pada pendederan ikan Oshpronemus goramy di setiap minggu menggunakan

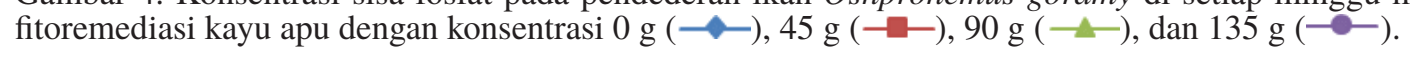

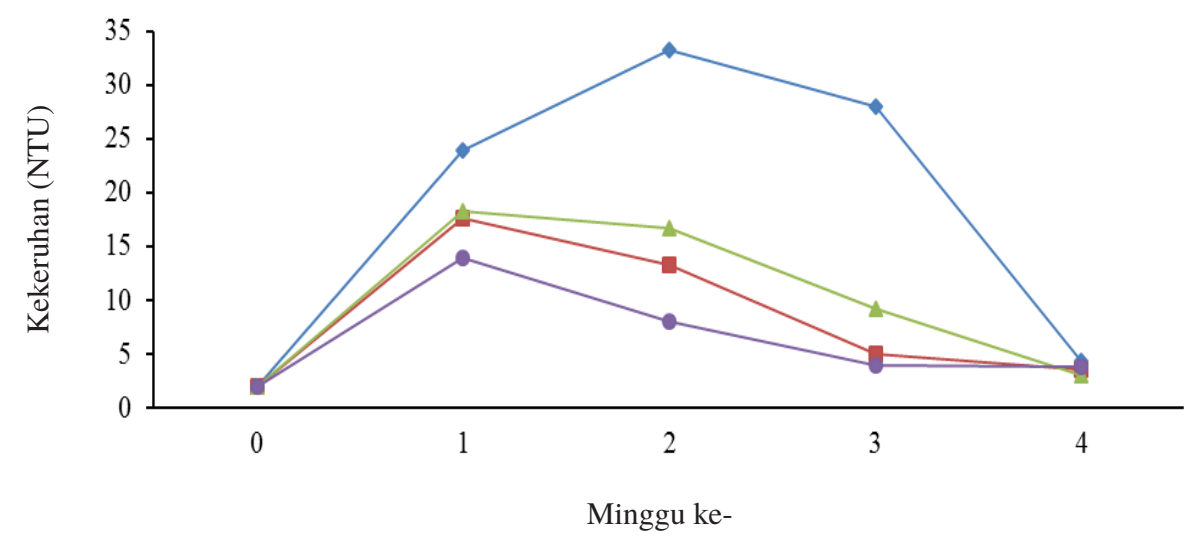

Gambar 5. Konsentrasi sisa kekeruhan pada pendederan ikan Oshpronemus goramy di setiap minggu menggunakan

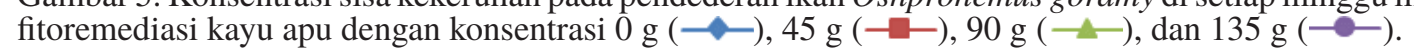


(Gambar 9). Berdasarkan uji statistik ragam (ANOVA) pada selang kepercayaan 95\%, nilai kontrol berbeda nyata dengan perlakuan kayu apu $45 \mathrm{~g}$ dan $135 \mathrm{~g}(\mathrm{P}<0,05)$. Nilai kontrol tidak berbeda nyata dengan perlakuan kayu apu $90 \mathrm{~g}$.

\section{Analisis biaya dan keuntungan}

Perhitungan biaya keuntungan pendederan ikan gurami yang diasumsikan untuk satu tahun dan terdiri atas enam siklus pendederan, jumlah akuarium 12 unit, tiap akuarium berisi 210 ekor benih, harga benih ukuran $3 \mathrm{~cm}$ Rp300,- dan harga jual saat panen Rp500,-. Berdasarkan Tabel 2 perhitungan biaya keuntungan dengan penerimaan tertinggi terdapat pada perlakuan kayu apu $45 \mathrm{~g}$ sebesar Rp1.821.000,- dengan keuntungan Rp507.000,- dan rasio R/C 1,39, sedangkan kontrol mendapat kerugian sebesar Rp797.000,- dengan rasio R/C sebesar 0,38.

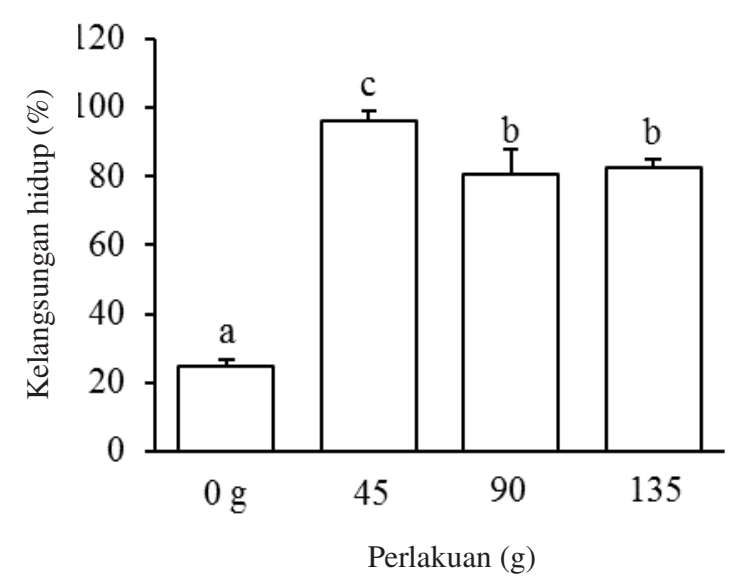

Gambar 6. Tingkat kelangsungan hidup (SR) ikan Oshpronemus goramy selama penelitian. Keterangan: Huruf berbeda di atas diagram batang menunjukan perbedaan yang nyata $(\mathrm{P}<0,05)$.

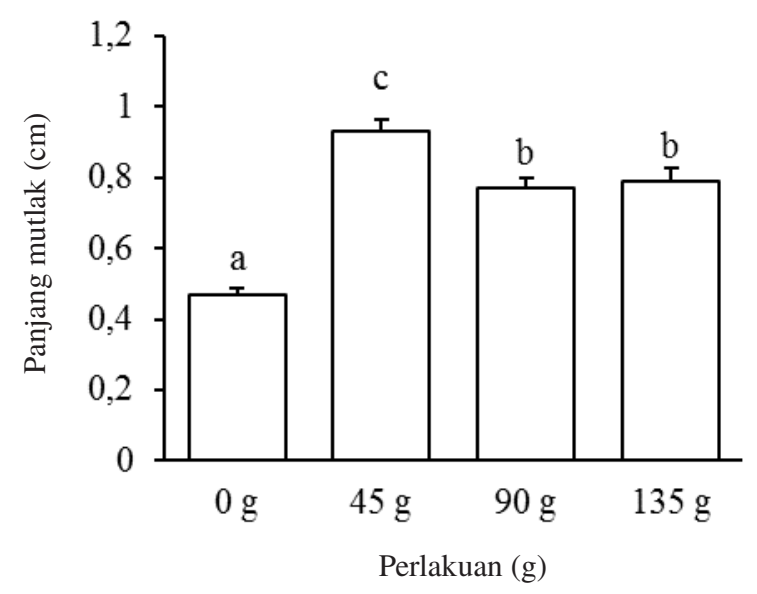

Gambar 8. Pertumbuhan panjang mutlak ikan gurami selama penelitian. Keterangan: huruf berbeda di atas diagram batang menunjukan perbedaan yang nyata $(\mathrm{P}<0,05)$.

\section{Pembahasan}

Hasil yang didapat selama penelitian menunjukkan konsentrasi amonia, nitrit, nitrat, fosfat, dan kekeruhan perlakuan $45 \mathrm{~g}$ menunjukkan hasil yang paling efektif dibandingkan dengan perlakuan lainnya. Nilai tingkat kelangsungan hidup, laju pertumbuhan harian, panjang mutlak, dan efisiensi pakan menunjukkan hasil yang berbeda nyata $(\mathrm{P}<0,05)$ antara perlakuan menggunakan fitoremediasi tanaman kayu apu dan kontrol. Tanaman kayu apu dalam penelitian ini berfungsi sebagai fitoremediator dalam media pemeliharan mampu menyerap amonium langsung dari hasil metabolisme ikan serta mampu mengadsorbsi partikel-partikel penyebab kekeruhan dibuktikan pada semua perlakuan kayu apu nilai sisa amonia mengalami penurunan dan juga nilai kekeruhan mengalami penurunan sampai akhir masa pemeliharaan. Indah et al.

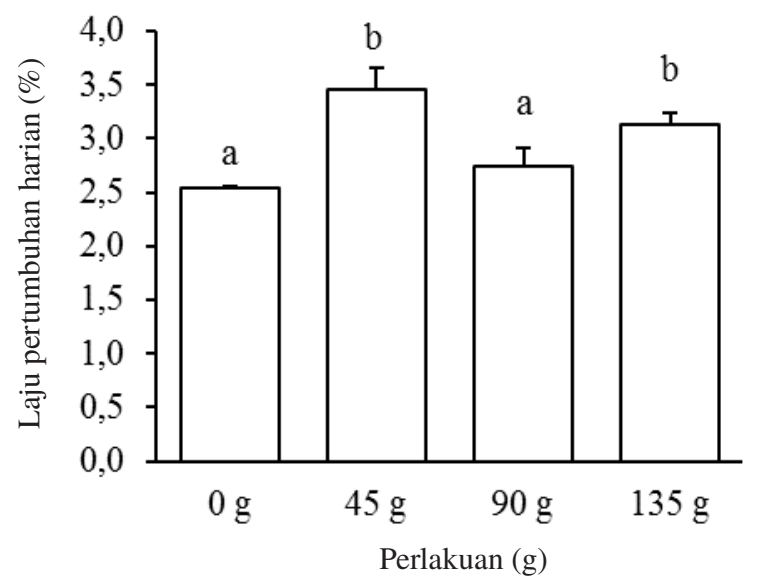

Gambar 7. Laju pertumbuhan harian (LPH) ikan Oshpronemus goramy selama penelitian. Keterangan: Huruf berbeda di atas diagram batang menunjukan perbedaan yang nyata $(\mathrm{P}<0,05)$.

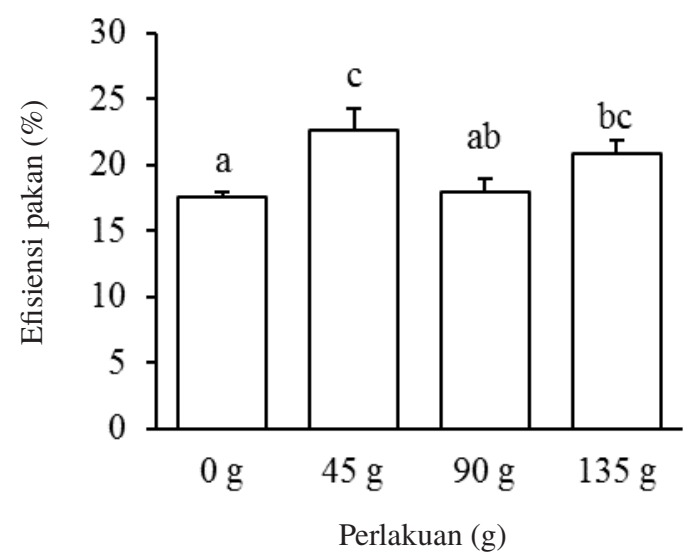

Gambar 9. Efisiensi pakan (EP) ikan gurami selama penelitian. Keterangan: huruf berbeda di atas diagram batang menunjukan perbedaan yang nyata $(\mathrm{P}<0,05)$. 
Tabel 2. Perhitungan biaya keuntungan pendederan ikan gurami Oshpronemus goramy dengan rasio bobot kayu apu berbeda

\begin{tabular}{lcccc}
\hline \multirow{2}{*}{ Parameter } & \multicolumn{4}{c}{ Perlakuan } \\
& Kontrol $(0 \mathrm{~g})^{*}$ & $\mathrm{~A}(45 \mathrm{~g})$ & $\mathrm{B}(90 \mathrm{~g})$ & $\mathrm{C}(135 \mathrm{~g})$ \\
\hline Pengeluaran (Rp) & 1.279 .000 & 1.314 .000 & 1.302 .000 & 1.307 .000 \\
Jumlah ikan awal (ekor) & 3.780 & 3.780 & 3.780 & 3.780 \\
SR (\%) & 25,50 & 96,33 & 80,67 & 82,33 \\
Harga jual (Rp) & 500 & 500 & 500 & 500 \\
Penerimaan (Rp) & 482.000 & 1.821 .000 & 1.524 .600 & 1.556 .500 \\
Keuntungan (Rp) & $(-797.000)$ & 507.000 & 222.600 & 249.500 \\
Rasio R/C & 0,38 & 1,39 & 1,17 & 1,19 \\
\hline
\end{tabular}

Keterangan: *mengalami kerugian.

(2014) juga menyatakan bahwa tanaman kayu apu dapat menurunkan komposisi bahan organik yang ada pada limbah tahu yang merupakan limbah protein.

Konsentrasi amonia yang tersisa di dalam media pemeliharaan berkisar antara 0,006-0,019 $\mathrm{mg} / \mathrm{L}$. Konsentrasi amonia meningkat di awal pemeliharaan. Hal ini dikarenakan tanaman $P$. stratiotes memanfaatkan langsung amonia nitrogen yang berasal dari sisa metabolisme gurami dan sisa pakan yang terakumulasi di dalam air. Tanaman air dapat langsung memanfaatkan $\mathrm{N}$ dari dalam air media budidaya (Okomoda et al., 2012). Sari et al. (2016) menyatakan pada suhu dan tekanan normal amonia $\left(\mathrm{NH}_{3}\right)$ berada dalam bentuk gas dan membentuk kesetimbangan dengan gas amonium $\left(\mathrm{NH}_{4}^{+}\right)$. Amonium ini yang dimanfaatkan langsung oleh tumbuhan sebagai pupuk. Sari (2016) menyatakan bahwa tingkat toleransi amonia bagi biota akuatik adalah tidak lebih dari 0,02 mg/L. Hal ini yang menyebabkan terjadinya kematian pada ikan gurami terutama pada perlakuan kontrol (kayu apu $0 \mathrm{~g}$ ).

Konsentrasi nitrit yang tersisa di media pemeliharaan berkisar antara 0,975-1,04 mg/L. Meskipun di perairan nitrit terdapat dalam jumlah yang sedikit, kadar nitrit yang melebihi $0,5 \mathrm{mg} / \mathrm{L}$ akan bersifat toksik bagi beberapa organisme air yang sensitif. Sumber nitrit di perairan adalah amonia, namun dalam hal ini amonia yang berikatan dengan air bereaksi menjadi amonium dimanfaatkan langsung oleh tumbuhan sebagai pupuk, sehingga proses nitrifikasi amonia menjadi nitrit berlangsung tidak optimal. Menurut Madhurina et al. (2013) bahan organik yang ada sebagai penyedia unsur hara bagi tanaman.

Pengukuran nitrat dimulai pada minggu ke dua pemeliharaan dengan rata-rata konsentrasi nitrat sisa yang terukur di media pemeliharaan sebesar 0,665-1,558 mg/L. Nilai nitrat cenderung turun di akhir pemeliharaan hal ini disebabkan proses nitrifikasi baru berlangsung dan nitrat yang merupakan nutrien bagi pertumbuhan baru dimanfaatkan oleh tanaman. Konsentrasi nitrat dalam perairan berkisar 0,1-5 mg/L (Smith et al., 2011), nilai nitrat yang didapat pada kontrol dan perlakuan masih berada dalam kisaran normal sehingga masih baik untuk kehidupan ikan gurami.

Konsentrasi fosfat yang terukur di dalam air sebesar 0,032-0,08 mg/L. Menurut Chen et al. (2015) fosfor umumnya diserap oleh tanaman sebagai ortofosfat $\left(\mathrm{H}_{2} \mathrm{PO}_{4}\right)$ dan fosfat sekunder $\left(\mathrm{HPO}_{4}^{2-}\right)$. Sama halnya dengan amonium dan nitrat, konsentrasi fosfat mengalami penurunan di akhir pemeliharaan karena fosfor dimanfaatkan oleh tanaman $P$. stratiotes untuk tumbuh. Kadar fosfor pada perairan alami berkisar antara 0,005$0,02 \mathrm{mg} / \mathrm{L} \mathrm{P}_{-} \mathrm{PO}_{4}$ (Kamil, 2012) dan masih berada dalam batas toleransi bagi ikan gurami serta kadar fosfat menunjukkan air dalam media pemeliharaan berada dalam tingkat kesuburan yang sedang.

Konsentrasi kekeruhan yang terukur di dalam media berkisar 3,0-18,3 NTU. Nilai kekeruhan pada perlakuan kayu apu 0 g lebih tinggi dibandingkan dengan perlakuan menggunakan kayu apu 45 g, 90 g, dan 135 g. Hal ini sesuai dengan penelitian yang dilakukan Marda (2015) yang mengatakan bahwa rata-rata kekeruhan pada perlakuan fitoremediasi cenderung bernilai lebih rendah dibandingkan perlakuan tanpa mengunakan tanaman dalam media pemeliharaannya.

Kandungan oksigen yang baik untuk budidaya perairan adalah antara 5-7 ppm (Kordi, 
2010). Kadar oksigen terlarut di bawah $3 \mathrm{mg} / \mathrm{L}$ akan membahayakan organisme perairan dan menyebabkan kematian. Nilai rata-rata oksigen terlarut selama pemeliharaan berkisar antara $6,17-7,77 \mathrm{mg} / \mathrm{L}$. Hingga akhir pemeliharaan nilai oksigen terlarut masih berada dalam kisaran yang baik untuk pemeliharaan. Nilai rata-rata suhu selama pemeliharaan berkisar $24,50-25,17{ }^{\circ} \mathrm{C}$. Menurut Kordi (2010) kisaran suhu optimal bagi kehidupan ikan di perairan tropis antara 25-32 ${ }^{\circ} \mathrm{C}$. Kisaran optimal $\mathrm{pH}$ adalah 7,5-8,7 (Kordi, 2010). Nilai rata-rata $\mathrm{pH}$ yang didapat selama pemeliharaan berkisar 7,50-8,26. Nilai $\mathrm{pH}$ yang mematikan bagi ikan yaitu kurang dari empat atau lebih dari 11. Kisaran $\mathrm{pH}$ selama penelitian masih dalam toleransi ikan gurami.

Tingkat kelangsungan hidup yang menggunakan tanaman menunjukkan hasil yang berbeda nyata dibandingkan kontrol $(\mathrm{P}<0,05)$. Tingkat kelangsungan hidup ikan menggunakan tanaman kayu apu $45 \mathrm{~g}$ menunjukkan hasil yang paling baik sebesar 96,33\% dibandingkan dengan kontrol dan perlakuan lainnya (Gambar 6). Hal ini sesuai dengan Effendi et al. (2006) yang mengatakan tingkat kelangsungan hidup ikan gurami dengan padat tebar 6 ekor/L dengan ukuran 2-3 cm yaitu 99,52\%. .

Laju pertumbuhan harian dan pertumbuhan panjang mutlak pada perlakuan $P$. stratiotes $45 \mathrm{~g}$ memberikan hasil yang berbeda nyata $(\mathrm{P}<0,05)$ dan pertumbuhan yang lebih tinggi dibandingkan dengan kontrol dan perlakuan lain. Nilai tersebut masingmasing sebesar 3,46 $\pm 0,19 \%$ (Gambar 7) dan $0,93 \pm 0,036 \mathrm{~cm}$ (Gambar 8). Besar kecilnya nilai efisiensi ekonomi dipengaruhi oleh beberapa factor seperti kepadatan, berat setiap individu, umur kelompok hewan, kualitas air dan cara pemberian pakan (Setiawati et al., 2013). Faktor kualitas yang buruk mengakibatkan stres pada tubuh ikan sehingga mudah terserang penyakit serta menurunkan nafsu makan. Nutrien yang ada di dalam pakan tidak dimanfaatkan dalam pertumbuhan namun untuk mempertahankan tubuh dari serangan penyakit. Penggunaan tanaman air dalam sistem budidaya dapat meningkatkan tingkat kehidupan ikan (Amalia, 2014). Nilai efisiensi pakan menunjukkan hasil yang berbeda nyata $(\mathrm{P}<0,05)$ antara kontrol dan perlakuan. Nilai efisiensi pakan tertinggi terdapat pada perlakuan tanaman P. stratiotes 45 g yaitu sebesar $22,61 \pm 1,71 \%$ dan terendah pada perlakuan kontrol sebesar 17,62 $\pm 0,29 \%$ (Gambar 9). Pakan yang diberikan dapat dimanfaatkan seluruhnya untuk pertumbuhan sehingga efisiensi pemberian pakannya tinggi. Pakan yang tidak termanfaatkan tersebut akan berpengaruh buruk terhadap kualitas air pemeliharaan ikan gurami.

Perhitungan biaya dilakukan pada akhir pemeliharaan dengan melihat nilai tingkat kelangsungan hidup akhir dan pertambahan panjang. Berdasarkan Tabel 2 yaitu perhitungan biaya pada pendederan ikan gurami pada kontrol dibandingkan dengan perlakuan tanaman $P$. stratiotes pada bobot yang berbeda dalam volume air $33 \mathrm{~L}$ diperoleh penerimaan yang paling besar terdapat pada perlakuan kayu apu $45 \mathrm{~g}$ sebesar Rp1.821.000,- dengan keuntungan yang diperoleh mencapai Rp507.000,- hal ini dikarenakan tingkat kelangsungan yang dihasilkan tinggi sehingga penerimaan yang didapat lebih banyak meskipun dari segi biaya pakan cukup tinggi juga.

Analisis rasio R/C merupakan parameter ekonomi yang digunakan untuk melihat seberapa banyak biaya yang digunakan untuk memberikan sejumlah penerimaan. Nilai rasio R/C tertinggi didapat pada perlakuan $45 \mathrm{~g}$ yaitu 1,39 (Tabel 2) yang menunjukkan setiap biaya Rp1,- yang dikeluarkan akan menghasilkan keuntungan sebesar Rp0,39,-. Nilai rasio R/C masing-masing perlakuan menunjukkan rasio $\mathrm{R} / \mathrm{C}$ lebih dari satu dan lebih baik dari kontrol, sehingga usaha pendederan ikan gurami menggunakan tanaman kayu apu dalam media pemeliharaannya lebih mengguntungkan secara ekonomi dibandingkan perlakuan tanaman kayu apu $0 \mathrm{~g}$.

\section{KESIMPULAN}

Perlakuan bobot kayu apu $45 \mathrm{~g}$ dengan volume air $33 \mathrm{~L}$ terbukti bermanfaat sebagai fitoremediator pada pendederan ikan gurami ukuran $3 \mathrm{~cm}$ paling baik dibandingkan perlakuan lain dan mampu menurunkan konsentrasi amonia hingga $0,006 \mathrm{mg} / \mathrm{L}$; nitrit hingga $0,975 \mathrm{mg} / \mathrm{L}$; nitrat hingga $0,665 \mathrm{mg} / \mathrm{L}$; fosfat hingga 0,032 $\mathrm{mg} / \mathrm{L}$ dan kekeruhan 3 NTU. Nilai kelangsungan hidup yang didapat mencapai $96,33 \%$, dari segi ekonomi menghasilkan keuntungan sebesar Rp 507.000,-.

\section{DAFTAR PUSTAKA}

Amalia F, Kukuh N, Enang H, Tri W. 2014. Kemampuan lemna Lemna perpusilla Torr. sebagai fitoremediator untuk menyerap limbah nitrogen dalam budidaya ikan lele Clarias gariepinus di sistem resirkulasi. LIMNOTEK- 
Perairan Darat Tropis di Indonesia 21: 185192.

APHA (American Public Health Association). 1989. Standard methods for the examination of water and wastewater, $17^{\text {th }}$ ed. Washington, DC: American Public Health Association.

Chen L, Xin Z, Bingcai P, Weixian Z, Ming H, Lu L, Weiming Z. 2015. Preferable removal of phosphate from water using hydrous zirconium oxide-based nanocomposite of high stability. Journal of Hazardous Materials 284: 35-42.

Effendi I, Bugri HJ, Widanarni. 2006. Pengaruh padat penebaran terhadap kelangsungan hidup dan pertumbuhan benih ikan gurami Osphronemus gouramy Lac. ukuran $2 \mathrm{~cm}$. Jurnal Akuakultur Indonesia 5: 127-135.

Effendie MI. 1997. Biologi Perikanan. Yogyakarta: Yayasan Pustaka Nusantara.

Fitria SN, Unggul PJ, Gancang S. 2014. Potensi tanaman genjer Limnocharis flava untuk mengurangi kadar logam berat $(\mathrm{Pb}$ dan $\mathrm{Cu}$ ) serta radionuklida dengan metode fitoremediasi. Physics Student Journal 2: 1-5.

Hadiyanto, Christwardana M. 2012. Aplikasi fitoremediasi limbah jamu dan pemanfaatannya untuk produksi protein. Jurnal Ilmu Lingkungan 10: 129-134.

Indah LS, Hendrarto B, Soedarsono P. 2014. Kemampuan enceng gondok Eichhornia sp. dan kayu apu Pistia sp. dalam menurunkan bahan organik limbah industri tahu (skala laboratorium). Diponegoro Journal of Maquares 3: 1-6.

Kamil MT. 2012. Status Mutu air sungai lampanang di kecamatan teweh timur Kabupaten Barito Utara. Journal of Tropical Fisheries 7: 601-605.

Kordi MG. 2010. Panduan lengkap memelihara ikan air tawar di kolam terpal. Yogyakarta: Lily Publisher.

Lu Q, Zhenli L, Donald A, Graetz, Peter J. Stoffela, Xiaoe Y. 2008. Phytoremediation to remove nutrient and improve eutrophic stromwater using water lettuce Pistia stratiotes L. Environmental Science Pollutan Research 17: 84-96.

Madhurina M, Bidisha M, Shekhar MM, Sankar
C, Amitawa G, Arunabha M. 2014. Study on the phytoremediation potential wastewater A case study in Indian context. International Research Journal of Environment Sciences 3: 83-89.

Marda AB, Kukuh N, Enang H, Eddy S. 2015. Efektivitas fitoremediator Lemna perpusilla pada media budidaya ikan gurami bersalinitas 3 ppt. Jurnal Akuakultur Indonesia 14: 122-127.

Okomoda VT, Solomon SG, Ataguba GA. 2012. Potential uses of the family Lemnaceae. Journal of Agriculture and Veterinary Sciences 4: 1-14.

Purwaningsih IS. 2009. Pengaruh penambahan nutrisi terhadap efektivitas fitoremediasi menggunakan tanaman eceng gondok Eichhornia crassipes terhadap limbah ortoklorofenol. Jurnal Rekayasa Proses 3: 5-9.

Sari SDM, I Wayan DS, I Gede M. 2016. Pemanfaatan biosistem tanaman untuk menurunkan kadar fenol, amonia, ion klorida, dan COD dari proses biodegradasi air limbah yang mengandung rhodamin B. Journal of Environmental Science $10: 1-8$.

Setiawati JE, Tarsim YT, Adiputra,Hudaidah S. 2013. Pengaruh penambahan probiotik pada pakan dengan dosis berbeda terhadap pertumbuhan, kelulushidupan, efisiensi pakan dan retensi protein ikan patin Pangasius hypophthalmus. Jurnal Rekayasa dan Teknologi Budidaya Perairan 1: 151-162.

Smith GR, Andrew JT, Christopher BD, Allison B, Megan EO, Christopher JD. 2011. Effects of Mosquitofish and ammonium nitrate on activity of green frog Lithobates clamitans tadpoles: a mesocosm experiment. Journal of Freshwater Ecology 26: 59-63.

Wirawan WA, Ruslan W, Lilliya DS. 2014. Pengolahan limbah cair domestik menggunakan tanaman kayu apu Pistia stratiotes L. dengan teknik tanam hidroponik sistem DFT (Deepflowtechnique). Jurnal Sumberdaya Alam dan Lingkungan 1: 63-70.

Zonneveld N, Huisman EA, Boon JH. 1991. Prinsip-prinsip budidaya ikan. Jakarta: PT. Gramedia Pustaka Umum. 